\title{
PENERAPAN MODEL PEMBELAJARAN PROBLEM POSING UNTUK MENINGKATKAN PRESTASI BELAJAR SISWA
}

\author{
Sri Rahayu Susilowati ${ }^{1}$, Edy Supriyadi ${ }^{2}$ \\ ${ }^{1}$ SMK Negeri 2 Depok, Sleman \\ ${ }^{2}$ Program Studi Pendidikan Teknik Elektro, Fakultas Teknik, Universitas Negeri Yogyakarta \\ email : ussieayupranata@gmail.com
}

\begin{abstract}
This study aims to determine whether the application of problem-posing learning methods can improve learning achievement competencies of Applying Electrical Circuits for Grade X students of Industrial Automation Engineering at SMK N 2 Depok. This research is a Classroom Action Research. The study was conducted in three cycles, cycle I three meetings, cycle II four meetings, and cycle III three meetings. Each cycle consists of four stages, namely planning, action, observation, and reflection. Data collection uses non-test (observation sheet) to find out the supporting components of learning and tests (pretest-posttest instrument) to find out the improvement of student learning achievement. Analysis of the data used in collecting data, reducing data, exposing data, and concluding data. In this research, it is known that after applying the Post Solution Type Problem Posing learning model, student competencies have increased in terms of the results of students' pretestposttest. Cycle I has a percentage of completeness pretest $0 \%$, posttest $28.1 \%$. Cycle II has a percentage of completeness pretest $0 \%$, posttest $68.75 \%$. Cycle III percentage of completeness pretest $0 \%$, posttest $75 \%$. On observation, there is an increase and decrease in each component in each cycle.
\end{abstract}

Keywords: classroom action research, problem posing, student achievement

\begin{abstract}
ABSTRAK
Penelitian ini bertujuan untuk mengetahui apakah penerapan metode pembelajaran problem posing dapat meningkatkan prestasi belajar kompetensi Mengaplikasikan Rangkaian Listrik siswa kelas X Teknik Otomasi Industri SMK N 2 Depok. Penelitian ini merupakan Penelitian Tindakan Kelas. Penelitian dilaksanakan dalam tiga siklus, siklus I tiga kali pertemuan, siklus II empat kali pertemuan, dan siklus III tiga kali pertemuan. Setiap siklus terdiri dari empat tahap yaitu perencanaan, tindakan, observasi, dan refleksi. Pengumpulan data menggunakan non tes (lembar observasi) untuk mengetahui komponen pendukung pembelajaran dan tes (instrumen pretest-posttest) untuk mengetahui peningkatan prestasi belajar siswa. Analisis data yang digunakan adalah mengumpulkan data, mereduksi data, memaparkan data, dan menyimpulkan data. Pada penelitian ini diketahui bahwa setelah diterapkan model pembelajaran Problem Posing tipe Post Solution Type, kompetensi siswa mengalami peningkatan ditinjau dari hasil pretest-posttest siswa. Siklus I memiliki persentase ketuntasan pretest $0 \%$ posttest $28,1 \%$. Siklus II memiliki persentase ketuntasan pretest $0 \%$, posttest $68,75 \%$. Siklus III persentase ketuntasan pretest $0 \%$ posttest $75 \%$. Pada observasi terjadi peningkatan dan penurunan pada setiap komponen di setiap siklus.
\end{abstract}

Kata kunci: penelitian tindakan kelas, problem posing, prestasi belajar siswa

\section{PENDAHULUAN}

Pendidikan kejuruan, termasuk Sekolah Menengah Kejuruan (SMK), merupakan pendidikan yang menekankan pada pengalaman praktik. Kegiatan pembelajarannya sebagian berlangsung di sekolah, sebagian di industri.
Pendidikan kejuruan dapat memberikan akses langsung ke pekerjaan atau melanjutkan menuju pendidikan tinggi (Danish: 2014).

Lulusan pendidikan kejuruan harus memiliki serangkaian kompetensi sesuai dengan yang dibutuhkan dunia kerja. Oleh 
karena itu, semua komponen penyelenggaraan pendidikan kejuruan, seperti kurikulum, tenaga pendidik, fasilitas, manajemen dan proses pembelajaran harus memenuhi standar yang ditentukan. Kualitas pembelajaran sangat mempengaruhi hasil belajar. Pembelajaran yang efektif adalah pembelajaran yang dapat meningkatkan pencapaian kompetensi siswa sedemikian rupa sehingga dapat menunjang keberhasilan siswa di masa mendatang (Coe: 2014). Peran Guru sangat penting dalam pembelajaran. Kualitas Guru sangat mempengaruhi sikap dan perilaku siswa, serta prestasi akademiknya (Blazar: 2016).

Terdapat cukup banyak masalah yang harus dihadapi oleh dunia pendidikan di Indonesia, termasuk Sekolah Menengah Kejuruan (SMK). Masalah-masalah yang dihadapi SMK antara lain rendahnya kualitas sebagian guru, kurangnya partisipasi masyarakat, tingginya tuntutan masyarakat, laju perkembangan teknologi yang sangat pesat, lemahnya proses pembelajaran dan sebagainya.

Pembaharuan Pendekatan pembelajaran merupakan salah satu upaya meningkatkan prestasi anak didik. Pembaharuan Pendekatan pembelajaran ditujukan untuk meningkatkan prestasi di bidang pendidikan sebagaimana diharapkan agar anak didik lebih siap menghadapi globalisasi. Peningkatan kualitas pembelajaran merupakan tuntutan logis perkembangan ilmu pengetahuan dan teknologi (Iptek) yang semakin pesat.

Program Keahlian Teknik Otomasi Industri SMKN 2 Depok Sleman juga ikut terus berusaha meningkatkan kemampuan lulusannya dengan memberikan bekal semaksimal mungkin pada siswa-siswi yang menjadi tanggung jawabnya. Upaya pemberian bekal yang semaksimal mungkin ini di antaranya dengan berusaha meningkatkan penguasaan siswa terhadap kompetensi kejuruan.

Kompetensi Mengaplikasikan Rangkaian Listrik merupakan salah satu kompetensi Dasar Kejuruan yang sangat penting untuk dikuasai oleh siswa Kompetensi Keahlian Teknik Otomasi Industri. Hampir setiap kompetensi kejuruan pada semester-semester berikutnya memerlukan kompetensi ini. Selama ini kompetensi Mengaplikasikan Rangkaian Listrik merupakan kompetensi yang cukup sulit dikuasai oleh siswa. Hal ini dibuktikan dengan sedikitnya siswa yang mencapai Kriteria Ketuntasan Minimal saat evaluasi pertama (sebelum remidial) dan rendahnya rata-rata nilai pestasi belajar siswa di kompetensi tersebut.

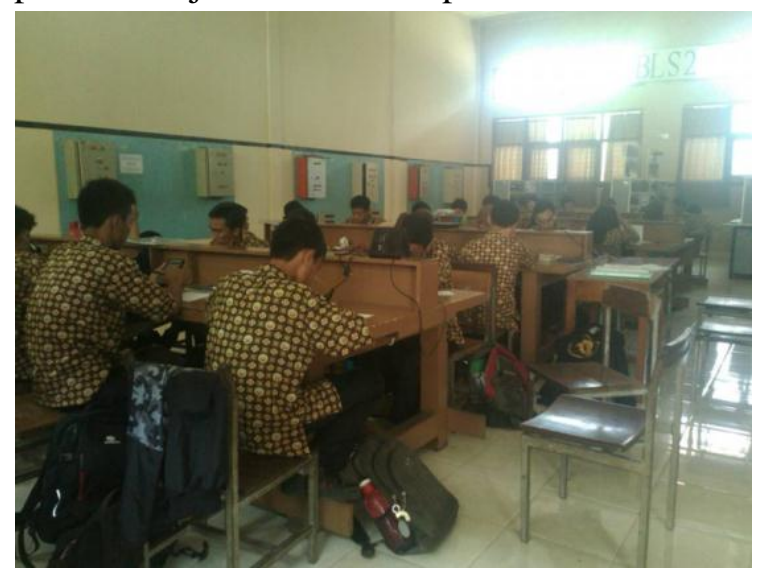

Gambar 1. Suasana Pembelajaran Teori Dasar Listrik dan Elektronikia di Bengkel Teknik Otomasi Industri

Rendahnya penguasaan kompetensi Mengaplikasikan Rangkaian listrik ini disebabkan oleh beberapa hal yaitu: minimnya waktu yang tersedia untuk menyelesaikan materi yang sangat banyak, guru masih dominan menggunakan metode pembelajaran ceramah, sebagian siswa kurang dalam penguasaan matematika sebagai kemampuan pendukung, sangat banyak materi perhitungan tetapi waktu untuk latihan soal sangat kurang, kondisi ruang yang kurang mendukung kenyamanan belajar, kurangnya waktu untuk praktek. Materi sulit dipahami jika hanya dengan teori, siswa cenderung kurang menyukai materi teori dan konsep-konsep tetapi lebih menyukai belajar langsung praktek. Di samping itu terbatasnya kemampuan guru dalam penguasaan media pembelajaran, dan model pembelajaran, serta kemampuan dasar siswa yang beragam merupakan masalah yang harus segera diatasi. 


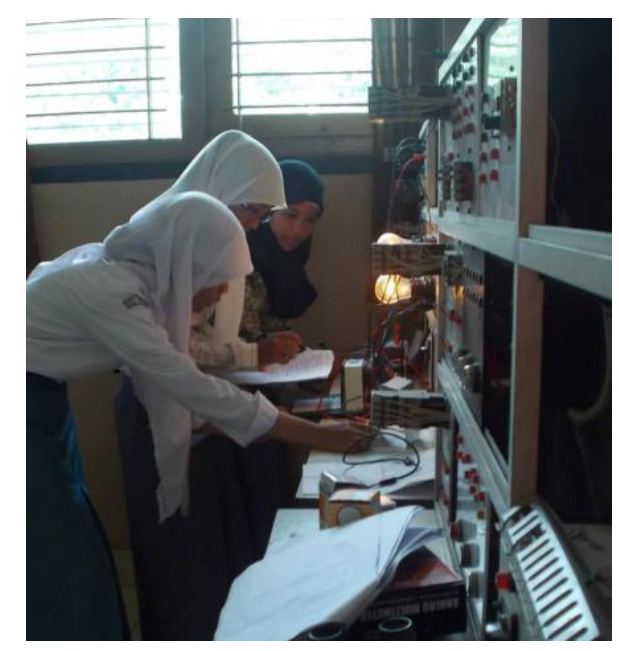

Gambar 2. Suasana Pembelajaran Praktek Dasar Listrik dan Elektronika di Bengkel Teknik Otomasi Industri

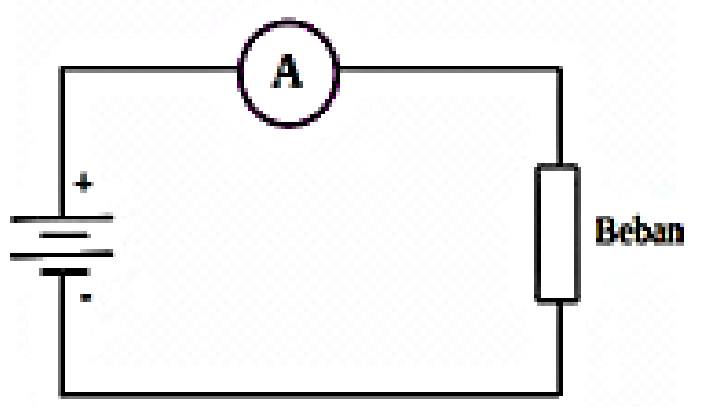

Gambar 3. Contoh Gambar Rangkaian yang dipraktekkan dalam Pembelajaran Dasar Listrik dan Elektronika di Bengkel Teknik Otomasi Industri

Rendahnya kemampuan siswa dalam penguasaan kompetensi Mengaplikasikan Rangkaian Listrik akan mempersulit siswa dalam mempelajari dan menguasai kompetensikompetensi lain terutama kompetensi kejuruan. Hal ini berakibat pada turunnya kualitas lulusan kompetensi keahlian Teknik Otomasi Industri. Memperhatikan hal tersebut, dipandang perlu untuk meningkatkan penguasaan siswa terhadap kompetensi Mengaplikasikan Rangkaian Listrik. Faktor-faktor yang telah disebutkan di atas jika diteliti seluruhnya akan memakan banyak waktu, tenaga dan biaya. Berdasarkan beberapa pertimbangan, maka pada penelitian ini yang diteliti hanya terbatas pada peningkatan prestasi belajar siswa dengan penerapan model pembelajaran Problem Posing pada kompetensi Mengaplikasikan Rangkaian
Listrik siswa klas X TOI SMKN 2 Depok, Sleman.

Model pembelajaran Problem Posing adalah model pembelajaran dimana siswa diminta untuk membuat soal dan pemecahannya atau jawabannya (Shoimin: 2014). Sebelum membuat soal beserta jawabannya diharapkan siswa mempelajari materi lebih dahulu dan berusaha memahaminya. Beberapa di antara soal-soal tersebut akan dibahas guru bersama siswa, kemudian dikumpulkan. Siswa diharapkan mengarsip soal-soal buatannya untuk belajar. Model pembelajaran Problem Posing sangat sesuai digunakan pada materi pembelajaran yang kompleks dan rumit, yang berkaitan dengan perhitungan matematis dan analisis (Rahman: 2017). Pembelajaran Problem Posing juga memberikan kesempatan kepada Guru untuk mendapatkan wawasan tentang proses berpikir siswa (Habila: 2017).

Alasan pemilihan model pembelajaran Problem Posing untuk meningkatkan prestasi belajar kompetensi Mengaplikasikan Rangkaian Listrik karena pada kompetensi ini sangat banyak materi perhitungan yang mirip matematika. Dengan membuat soal dan penyelesaiannya siswa harus mempelajari materi lebih dahulu. Jika siswa tidak belajar lebih dahulu siswa tidak akan menguasai materi. Jika siswa tidak menguasai materi, siswa tidak akan mampu membuat soal dan penyelesaiannya. Jadi dengan model pembelajaran Problem Posing ini sebagian siswa yang kadang tidak belajar menjadi harus belajar.

Menurut Mahmudi (2008) Problem Posing diklasifikasikan menjadi tiga jenis, yaitu: Problem Posing tipe Post Solution Posing, Problem Posing tipe Within Solution Posing, dan Problem Posing tipe Pre-Solution Posing. Penelitian ini menerapkan Model Pembelajaran Problem Posing tipe Post Solution Posing. Langkah-langkah Problem Posing tipe Post Solution Posing adalah: guru menyampaikan tujuan pembelajaran dan memotivasi siswa untuk belajar, guru 
menyajikan informasi baik dengan handout, secara ceramah atau tanya jawab selanjutnya memberi contoh soal dan cara pemecahannya berdasar informasi yang diberikan, guru memberikan latihan soal secukupnya untuk dikerjakan siswa di kelas, guru menugaskan siswa untuk membuat beberapa soal yang sesuai dengan materi yang sedang dibahas berserta jawabannya. Diharapkan soal yang dibuat lebih berbobot dari contoh dan soal latihan yang diberikan guru, guru secara acak atau selektif berdasar bobot soal meminta beberapa siswa maju untuk menulis soal dan jawabannya di depan kelas, guru dan siswa bersama-sama membahas soal tersebut. Guru meminta siswa untuk mengumpulkan soal-soal beserta jawabannya dan siswa harus punya arsipnya.

\section{METODE}

\section{Jenis Penelitian ini adalah Penelitian Tindakan Kelas Kolaborasi dengan menggunakan desain PTK model Kemmis dan Taggart. Komponen acting (tindakan) dengan observing (pengamatan) dijadikan menjadi satu kesatuan. Satu kesatuan di sini dimaksudkan bahwa kedua tindakan tersebut dilaksanakan secara bersamaan ketika proses penelitiaan dilakukan.}

Siklus penelitian ini tergantung dari tercapainya tujuan penelitiannya. Apabila tujuan penelitian terlah tercapai maka siklus berikutnya tidak dilaksanakan. Setiap siklus terdiri dari empat tahapan, yaitu Perencanaan (plan), Tindakan (Act), Observasi (Observe), dan refleksi (reflect).

Waktu penelitian ini dilaksanakan 3 bulan, yaitu pada 4 September hingga 30 November 2018. Pembelajaran dengan metode pembelajaran Problem Posing pada mata pelajaran Mengaplikasikan Rangkaian Listrik dilaksanakan pada rentang waktu tersebut.

Penelitian dilakukan di SMK N 2 Depok yang beralamat di Kampung Mrican, Caturtunggal, Depok, Sleman. Penelitian dilaksanakan di Bengkel Teknik Otomasi Industi tepatnya di Laboraturium Elektronika dan Mikrokontroler yang di dalamnya terdapat media pembelajaran yang dapat menunjang proses pembelajaran.

Subyek Penelitian ini adalah sebanyak 32 siswa klas X Teknik Otomasi Industri SMK N 2 Depok, Sleman tahun ajaran 2018/2019. Karena kelas hanya ada 1, maka untuk pembanding yang tidak diterapkan model pembelajaran problem posing digunakan kelas tahun sebelumnya (2017/2018)

Setting Tindakan direncanakan terdiri dari beberapa siklus. Tiap-tiap siklus meliputi perencanaan, Pelaksanaan Tindakan dan observasi dan Refleksi. Tahap perencanaan terdiri dari; merancang langkah-langkah pembelajaran dengan metode Problem Posing, membuat RPP, menyiapkan materi, menyiapkan instrumen observasi, menyiapkan instrumen tes kognitif, menyiapkan alat/media yang diperlukan, dan menentukan kriteria keberhasilan. Tahap Pelaksanaan Tindakan dan observasi meliputi; memberikan apersepsi pada siswa berkaitan materi yang akan dibahas, melaksanakan pretest, menyampaikan materi pada siswa, memberikan contoh soal beserta pemecahannya sekaligus membahasnya bersama siswa, memberikan latihan soal untuk dikerjakan siswa kemudian membahas bersama siswa, memberikan tugas pada siswa untuk membuat sendiri soal berdasar materi yang sedang dibahas dan pemecahannya, meminta beberapa siswa secara acak atau selektif berdasar bobot soal untuk mengerjakan soalnya di depan kelas dan membahasnya bersamasama, mengumpulkan tugas soal beserta jawaban yang dibuat siswa, melaksanakan posttes, memantau dan mencatat/merekam secara cermat semua apa yang terjadi selama proses tindakan dan mengisi lembar observasi, mencatat gagasan-gagasan yang mungkin muncul selama proses pembelajaran, melakukan evaluasi terhadap hal-hal yang telah direncanakan setiap kali akan mengakhiri penggalan kegiatan. Tahap refleksi dengan 
melakukan; berdasarkan apa yang sudah dilaksanakan, kemudian dilakukan kajian apa yang sudah terjadi, apa yang sudah atau belum dihasilkan, apa yang belum tuntas untuk menentukan kegagalan atau keberhasilan pencapaian tujuan kemudian jika masih ada kekurangan atau kegagalan, maka dipikirkan faktor-faktor penyebabnya. Dalam tahap refleksi ini dilanjutkan dengan menetapkan langkah selanjutnya berdasar renungan tentang kelemahan dan kekuatan tindakan yang telah dilakukan, perkiraan peluang keberhasilan yang akan diperoleh, kendala atau kesulitan bahkan ancaman yang mungkin dihadapi kemudian diakhiri dengan mendiskusikan hasil refleksi untuk membuat kesimpulan dan keputusan.

Teknik pengumpulan data pada penelitian ini adalah tes dan non tes. Peneliti melakukan tes dua kali, yaitu untuk mengukur prestasi siswa sebelum tindakan (pretest) dan setelah tindakan (posttest), diadakan pada masing-masing siklus. Hasil data yang diperoleh melalui pretest dan posttest akan dianalisis untuk kemudian ditarik kesimpulan terkait penelitian yang telah dilaksanakan. Instrumen non tes yang digunakan dalam penelitian ini adalah observasi. Observasi dilakukan dengan cara peneliti melakukan pengamatan kemudian melakukan pencatatan dari hasil observasi. Proses observasi dilaksanakan tanpa mengganggu proses pembelajaran. Bentuk lembar observasi yang digunakan berupa daftar penilaian skala 1 sampai 4 yang diisi oleh para observer pada saat kegiatan pembelajaran.

Indikator keberhasilan digunakan peneliti sebagai penanda target dalam penelitian ini. Penelitian ini dinyatakan berhasil apabila telah terjadi peningkatan kompetensi mengaplikasikan rangkaian listrik melalui penerapan metode pembelajaran Problem Posing dan persentase ketuntasan siswa yang memenuhi KKM lebih dari $70 \%$ dari keseluruhan siswa kelas $\mathrm{X}$ TOI. Kriteria Ketuntasan Minimal untuk mata pelajaran Mengaplikasikan Rangkaian Listrik adalah 78.
Analisis data dalam penelitian tindakan kelas ini dilakukan menggunakan tiga tahap. Tahap pertama reduksi data, yaitu data yang telah diperoleh diseleksi sesuai dengan fokus masalah yang dihadapi. Pada tahapan ini seorang guru atau peneliti mengumpulkan data lalu dikelompokkan berdasarkan fokus masalah atau hipotesis, data yang dihasilkan dapat diperoleh dari obeservasi, hasil tes hasil belajar dan data catatan harian, kemudian ditambahkan dari hasil wawancara namun kemungkinan pada tahapan ini guru atau peneliti bisa membuat data yang dianggap tidak relevan. Tahap kedua, yaitu mendiskripsikan data dalam bentuk naratif, membuat grafik atau menyusun tabel. Tahap ketiga yaitu membuat sebuah kesimpulan berdasarkan deskripsi data yang telah diperoleh.

Penelitian ini menggunakan analisis kualitatif dan kuantitatif. Data kuantitatif dilakukan dengan menggunakan perhitungan kuantitatif berupa perhitungan persentase (\%), sedangkan data kualitatif dianalisis dengan penilaian-penilaian kualitatif (katagori).

\section{HASIL DAN PEMBAHASAN}

Menurut Nurkancana (1986: 62), bahwa prestasi belajar adalah hasil atau taraf kemampuan yang telah dicapai siswa atau peserta didik setelah mengikuti proses belajar mengajar dalam waktu tertentu baik berupa perubahan tingkah laku, keterampilan serta pengetahuan yang kemudian diukur dan dinilai kemudian diwujudkan dalam bentuk angka atau pernyataan.

Model pembelajaran adalah suatu rancangan atau pola yang digunakan sebagai pedoman pembelajaran di kelas. Artinya, model pembelajaran adalah suatu rancangan yang digunakan guru untuk melakukan pengajaran di kelas (Ngalimun: 2014).

Pelaksanaan Penelitian Tindakan Kelas (PTK) dengan penerapan model pembelajaran problem posing untuk meningkatkan prestasi belajar siswa pada kelas X TOI SMKN 2 Depok Sleman tahun pelajaran 2018/2019 
dilaksanakan dari bulan September sampai November 2018. Penelitian ini dilaksanakan dalam tiga siklus. Siklus I ada tiga kali tatap muka. Siklus III ada empat kali tatap muka. Siklus III ada tiga kali tatap muka.

Pelaksanaan proses pembelajaran dengan penerapan model pembelajaran problem posing dengan langkah-langkah sebagai berikut: pada kegiatan pendahuluan guru atau peneliti menyampaikan bahwa kegiatan pembelajaran berikutnya akan disampaikan dengan menerapkan model pembelajaran problem posing. Pada proses pembelajaran, saat kegiatan awal, guru mengecek kehadiran siswa dan memberikan apersepsi, memotivasi siswa, menyampaikan topik pembelajaran, dan tujuan pembelajaran .

Kegiatan inti pada pertemuan pertama tiap siklus diawali dengan melakukan pretest, sedangkan jika bukan pertemuan pertama siklus, diawali dengan membahas soal dan jawaban soal yang dibuat siswa di rumah. Setelah posttest, siswa akan diminta mempelajari materi pada handout yang telah dibagikan. Selanjutnya guru akan menjelaskan materi tersebut. Setelah guru menjelaskan halhal pokok materi, diadakan forum tanya jawab antara guru dengan siswa, dan siswa dengan siswa. Pada forum tanya jawab, siswa dibagi menjadi kelompok-kelompok kecil dengan anggota kelompok siswa yang saling berdekatan. Setelah tanya jawab selesai, guru memberikan contoh soal dan membahas bersama siswa. Setelah selesai membahas contoh soal, guru memberi latihan soal untuk dikerjakan siswa dan guru membimbing siswa yang kesulitan dalam mengerjakan soal kemudian salah satu siswa mengerjakan soal tersebut di depan kelas. Langkah berikutnya, guru memberikan tugas pada siswa untuk membuat soal dan jawabannya di kelas dengan memberi batasan waktu. Saat siswa membuat soal, guru berkeliling memeriksa soal yang dibuat siswa. Setelah selesai waktu pembuatan soal, guru meminta satu atau dua murid yang soalnya berbobot untuk menuliskan soal yang dibuat dan jawabannya di depan kelas. Soal yang telah ditulis tersebut, selanjutnya dibahas bersama guru dengan siswa. Pada akhir kegiatan inti, guru menugaskan siswa untuk membuat soal dan jawabannya di rumah. Soal dan jawaban yang dibuat siswa di rumah tersebut akan dikumpulkan pada pertemuan berikutnya. Pada tatap muka terakhir tiap siklus, guru mengganti tugas pembuatan soal di rumah tersebut dengan memberikan postest sebagai bahan evaluasi terhadap peningkatan hasil belajar siswa.

Pada tahap pengamatan prestasi dan ketuntasan belajar siswa, nilai ketuntasan belajar siswa Siklus I Kompetensi Dasar Mengaplikasikan Rangkaian Listrik Arus Searah mengalami peningkatan yaitu persentase ketuntasan pretest $0 \%$ meningkat pada posttest dengan persentase ketuntasan $28,1 \%$. Berdasarkan hasil tersebut, Siklus I kompetensi dasar mengaplikasikan rangkaian listrik arus searah persentase kelulusannya meningkat sebesar $28,1 \%$. Pada siklus I/ materi I belum mengalami peningkatan yaitu dari 32 siswa terdapat 9 siswa telah memenuhi KKM, dibandingkan dengan tahun ajaran 2017/2018 pada KD yang sama siswa yang memenuhi KKM sebanyak 11 siswa dari 32 siswa. Berdasar data tersebut maka dapat disimpulkan Siklus I Kompetensi Dasar Mengaplikasikan Rangkaian Listrik Arus Searah pada Tahun Ajaran 2018/2019 yang sudah menerapkan model pembelajaran Problem Posing jumlah siswa yang memenuhi KKM menurun jika dibandingkan dengan tahun ajaran 2017/2018 yang belum menerapkan model pembelajaran Problem Posing. Selain mengalami penurunan, prestasi belajar juga belum memenuhi indikator pencapaian target yaitu $70 \%$ siswa tuntas dengan KKM 78.

Nilai ketuntasan belajar siswa Siklus II Kompetensi Dasar Mengaplikasikan Rangkaian Kemagnitan mengalami peningkatan yaitu dengan persentase ketuntasan pretest $0 \%$ meningkat pada posttest dengan persentase ketuntasan $68,75 \%$. Berdasarkan hasil tersebut, 
siklus II kompetensi dasar mengaplikasikan rangkaian kemagnitan dengan persentase ketuntasan meningkat 40,65\% dari siklus I. Pada siklus II terjadi peningkatan yaitu dari 32 siswa terdapat 22 siswa yang memenuhi KKM, dibandingkan dengan Tahun Ajaran 2017/2018 pada KD yang sama siswa yang lulus KKM sebanyak 8 siswa dari 32 siswa. Berdasar data tersebut, maka dapat disimpulkan Siklus II Kompetensi Dasar Mengaplikasikan Rangkaian Kemagnitan pada Tahun Ajaran 2018/2019 yang sudah menerapkan model pembelajaran Problem Posing jumlah siswa yang memenuhi KKM meningkat dibandingkan dibandingkan Tahun Ajaran 2017/2018 yang belum menerapkan model pembelajaran problem posing. Meskipun sudah terjadi peningkatan prestasi belajar, tetapi belum memenuhi indikator pencapaian target yaitu $70 \%$ siswa tuntas dengan KKM 78.

Nilai ketuntasan belajar siswa siklus III Kompetensi Dasar Menganalisa Rangkaian Arus Bolak-Balik Satu Phasa mengalami peningkatan yaitu dengan persentase ketuntasan pretest $0 \%$, meningkat pada posttest dengan persentase ketuntasan $75 \%$. Berdasarkan hasil tersebut, siklus III kompetensi dasar menganalisa rangkaian arus bolak-balik satu phasa persentase ketuntasan meningkat $6,25 \%$ dari siklus II. Pada siklus III/ materi III terjadi peningkatan yaitu dari 32 siswa terdapat 24 siswa yang memenuhi KKM, jika dibandingkan dengan Tahun Ajaran 2017/2018 pada KD yang sama siswa yang lulus KKM sebanyak 13 siswa dari 32 siswa. Berdasar data tersebut, dapat disimpulkan Siklus III Kompetensi Dasar Menganalisa Rangkaian Arus Bolak-Balik Satu Phasa pada Tahun Ajaran 2018/2019 yang sudah menerapkan Model Pembelajaran Problem Posing jumlah siswa yang memenuhi KKM meningkat dibandingkan Tahun Ajaran 2017/2018 yang belum menerapkan Model pembelajaran Problem Posing. Pada Siklus III Tahun Ajaran 2018/2019, selain mengalami peningkatan, juga sudah memenuhi indikator pencapaian target yaitu $70 \%$ siswa tuntas dengan KKM 78.

Tabel 1. Ketuntasan hasil belajar siswa (Posttest) tanpa penerapan model pembelajaran Problem Posing

\begin{tabular}{c|c|c}
\hline Materi & $\begin{array}{c}\text { Ketuntasan } \\
\text { Siswa }\end{array}$ & $\begin{array}{c}\text { Ketuntasan } \\
\text { Klasikal }\end{array}$ \\
\hline I & 11 & $34,38 \%$ \\
II & 8 & $25 \%$ \\
III & 13 & $40,63 \%$ \\
\hline \multicolumn{2}{l}{ Jumlah siswa : 32} \\
\hline
\end{tabular}

Tabel 2. Ketuntasan hasil belajar siswa dengan penerapan Model pembelajaran Problem Posing

\begin{tabular}{c|c|c|c|c}
\hline $\begin{array}{c}\text { Materi } \\
\text { (Siklus) }\end{array}$ & \multicolumn{2}{|c|}{$\begin{array}{c}\text { Ketuntasan } \\
\text { Siswa }\end{array}$} & \multicolumn{2}{c}{$\%$ ketuntasan } \\
\cline { 2 - 5 } & Pretest & Posttest & Pretest & Posttest \\
\hline I & 0 & 9 & 0 & 28,1 \\
II & 0 & 22 & 0 & 68,75 \\
III & 0 & 24 & 0 & 75 \\
\hline
\end{tabular}

Jumlah siswa: 32

Berdasar pengamatan prestasi belajar siswa dari Siklus I sampai siklus III dapat disimpulkan bahwa Prestasi Belajar Mengaplikasikan Rangkaian Listrik siswa kelas $\mathrm{X}$ TOI SMK N 2 Depok Sleman dapat ditingkatkan dengan Model Pembelajaran Problem Posing. . Temuan penelitian ini selaras dengan hasi penelitian Zahra (2013), yaitu implementasi pembelajaran dengan problem posing dapat meningkatkan semangat belajar dan hasil belajar pada materi pembelajaran yang kompleks, seperti Matematika dan Sains.

Hasil penelitian yang relevan dengan penelitian ini berjudul "Penerapan Model Pembelajaran Problem Posing pada Praktek Kerja Bangku di SMK Muhammadiyah Prambanan" dengan hasil terdapat perbedaan hasil belajar mata pelajaran praktek kerja bangku siswa yang menerapkan model pembelajaran konvensional dengan model pembelajaran Problem Posing. Model Pembelajaran Problem Posing memberikan hasil belajar praktek Kerja Bangku yang lebih baik pada siswa kelas X SMK Muhammadiyah Prambanan. 
Pada tahap pengamatan observasi, observasi yang digunakan meliputi 6 komponen yaitu: kondisi siswa selama proses tindakan, kondisi guru, materi, pengelolaan kelas, komponen sarana, dan lingkungan.

Pada komponen siswa dalam pengamatan observasi hal yang diperhatikan yaitu: keaktifan siswa, perhatian siswa, kedisiplinan, penugasan atau resitasi, dan penguasaan siswa terhadap materi. Hasil observasi rata-rata yang diperoleh pada siklus I adalah $60,4 \%$ dengan rincian keaktifan siswa sebsar $83,3 \%$, perhatian siswa $41,7 \%$, kedisiplinan $83,3 \%$, penugasan atau resitasi $66,7 \%$, dan penguasaan materi $50 \%$, berdasarkan analisis hasil tersebut secara umum siswa masih kurang antusias dengan pembelajaran yang diberikan bahkan masih banyak siswa yang terlambat masuk ke kelas. Dari data tersebut, hal yang harus ditingkatkan untuk siklus berikutnya adalah perhatian siswa dan penguasaan materi.

Hasil rata-rata observasi yang diperoleh pada siklus II adalah $79,2 \%$ dengan rincian keaktifan siswa sebsar $75 \%$, perhatian siswa $83,3 \%$, kedisiplinan $83,3 \%$, penugasan atau resitasi $75 \%$, dan penguasaan materi $75 \%$. Berdasarkan analisis hasil tersebut beberapa siswa sudah antusias dengan pembelajaran yang diberikan namun, masih terdapat siswa yang ramai dengan temannya sehingga guru harus menegurnya agar kelas menjadi kondusif.

Hasil rata-rata observasi yang diperoleh pada siklus III adalah $85,4 \%$ dengan rincian keaktifan siswa sebesar $75 \%$, perhatian siswa $75 \%$, kedisiplinan $100 \%$, penugasan atau resitasi $91,7 \%$, dan penguasaan materi $75 \%$. Berdasarkan analisis hasil tersebut beberapa siswa antusias dengan pembelajaran yang diberikan, siswa sudah tepat waktu datang ke kelas, mampu mengerjakan soal latihan dan mengerjakan dengan maksimal.

Beberapa cara yang dapat dilakukan telah dilakukan guru untuk meningkatkan antusiame siswa adalah dengan memberi contoh-contoh nyata atau contoh aplikasi dalam kehidupan sehari-hari maupun dunia industri dan guru menggunakan media yang telah tersedia didalam ruangan tersebut. Selain itu guru juga dapat memanfaatkan video pembelajaran untuk lebih meningkatkan antusia siswa. Pemberian latihan soal yang bervariatif juga memotivasi siswa untuk lebih banyak mengajukan pertanyaan.

Pada komponen guru dalam pengamatan observasi hal yang diperhatikan yaitu: penguasaan materi, sistematika penyajian, penerapan metode, penggunaan metode, performance, dan pemberian motivasi. Hasil observasi rata-rata yang diperoleh pada siklus I adalah $81,3 \%$ dengan rincian penguasaan materi sebesar $75 \%$, sistematika penyajian $83,3 \%$, penerapan metode $83,3 \%$, penggunaan media $83,3 \%$, performance $75 \%$ dan pemberian masalah $83,3 \%$. Berdasarkan analisis hasil tersebut guru kurang jelas dalam menerangkan ketika diawal pertemuan dan pada pertemuan selanjutnya guru sudah jelas dalam menerangkan.

Hasil rata-rata observasi yang diperoleh pada siklus II adalah $72,9 \%$ dengan rincian penguasaan materi $75 \%$, sistematika penyajian $75 \%$, penerapan metode $75 \%$, penggunaan media $75 \%$, performance $58,3 \%$ dan pemberian masalah $83,3 \%$, berdasarkan analisis hasil tersebut guru sudah dengan baik menjelaskan materi yang diberikan, mampu memanfaatkan media yang ada, mampu menjawab pertanyaan dari siswa dengan baik, dan pemberian contoh soal yang variatif, tetapi performance masih perlu ditingkatkan pada siklus berikutnya.

Hasil rata-rata observasi yang diperoleh pada siklus III adalah $77,1 \%$ dengan rincian penguasaan materi $75 \%$, sistematika penyajian $83,3 \%$, penerapan metode $75 \%$, penggunaan media $75 \%$, performance $58,3 \%$ dan pemberian masalah $75 \%$. Berdasarkan analisis hasil tersebut guru sudah dengan baik menjelaskan materi yang diberikan, mampu memanfaatkan media yang ada, mampu menjawab pertanyaan dari siswa dengan baik, dan pemberian contoh soal yang variatif dan penyampaian materi 
dilakukan dengan runtut, jelas, dan lebih komunikatif

Pada komponen materi dalam pengamatan observasi hal yang diperhatikan yaitu: kesesuaian dengan isi kurikulum, sistematika penyampaian materi, urgensi, dan menarik. Hasil observasi rata-rata yang diperoleh pada siklus I adalah 83,3\% dengan rincian kesesuaian dengan isi kurikulum $100 \%$, sistematika penyampaian materi $83,3 \%$, urgensi $83,3 \%$, dan menarik $66,7 \%$. Berdasarkan analisis hasil tersebut pada pertemuan pertama sistematika materi yang disampaikan belum terlalu jelas kemudian pada pertemuan kedua materi belum merujuk dari yang nyata ke abstrak namun penyampaian materi sudah cukup jelas.

Hasil rata-rata observasi yang diperoleh pada siklus II adalah 79,8\% dengan rincian kesesuaian dengan isi kurikulum $75 \%$, sistematika penyampaian materi $75 \%$, urgensi $75 \%$, dan menarik $58,3 \%$. Berdasarkan analisis hasil tersebut pada pertemuan pertama sistematika materi yang disampaikan sudah runtut dan sesuai SK dan KD, namun pada pertemuan kedua terjadi trouble dengan LCD sehingga tampilan menjadi kecil dan kurang menarik.

Hasil rata-rata observasi yang diperoleh pada siklus III adalah $83,3 \%$ dengan rincian kesesuaian dengan isi kurikulum $75 \%$, sistematika penyampaian materi $83,3 \%$, urgensi $100 \%$, dan menarik $75 \%$. Berdasarkan analisis hasil tersebut pada materi yang disampaikan sudah runtut, respon siswa sudah baik, dan tugas-tugas yang diberikan dikerjakan lebih baik oleh siswa.

Faktor lain yang dapat dilakukan oleh guru agar materi tersampaikan dengan baik adalah pemanfaatan media yang tersedia pada ruangan tersebut sehingga siswa lebih dengan mudah menyerap informasi terhadap materi yang diberikan dan penekanan pada materi materi yang penting terutama yang berkaitan dengan dunia industri maupun kehidupan sehari-hari.

Pada komponen perngolalaan kelas dalam pengamatan observasi hal yang diperhatikan yaitu: tujuan, ruang, tempat duduk, dan siswa. Hasil observasi rata-rata yang diperoleh pada siklus I adalah 50\% dengan rincian tujuan $66,7 \%$, ruang $41,7 \%$, tempat duduk $25 \%$, dan siswa $66,7 \%$. Berdasarkan analisis hasil tersebut ruangan yang digunakan pada awal pertemuan tidak sesuai standar. Pada pertemuan selanjutnya telah memenuhi standar, tempat duduk yang kurang nyaman dan jaraknya terlalu dekat sehingga siswa lebih antusias dengan temannya daripada mendengarkan penjelasan guru akibatnya tujuan pembelajaran kurang maksimal tercapai.

Hasil rata-rata observasi yang diperoleh pada siklus II adalah $72,9 \%$ dengan rincian tujuan $100 \%$, ruang $58,3 \%$, tempat duduk $58,3 \%$, dan siswa $75 \%$. Berdasarkan analisis hasil tersebut siswa sudah mulai dapat dikondisikan dengan kondusif namun ada satu dua siswa yang masih tidak memperhatikan, namun ruang yang bersebelahan dengan kelas lain terkadang konsentrasi siswa menjadi terpecah.

Hasil rata-rata observasi yang diperoleh pada siklus III adalah $68,8 \%$ dengan rincian tujuan $75 \%$, ruang $58,3 \%$, tempat duduk $66,7 \%$, dan siswa $75 \%$. Berdasarkan analisis hasil tersebut pengelolaan kelas sudah cukup bagus dengan siswa sudah termotivasi untuk mengikuti pembelajaran dengan baik.

Komponen sarana dalam pengamatan observasi hal yang diperhatikan yaitu: ketersediaan sarana pembelajaran, penempatan sarana pembelajaran, kebermaknaan sarana pembelajaran, dan kelayakan sarana pembelajaran. Hasil observasi rata-rata yang diperoleh pada siklus I adalah 60,4\% dengan rincian ketersediaan sarana pembelajaran $58,3 \%$, penempatan sarana pembelajaran $66,7 \%$, kebermaknaan sarana pembelajaran 
$50 \%$, dan kelayakan sarana pembelajaran $66,7 \%$.

Hasil rata-rata observasi yang diperoleh pada siklus II adalah $72,9 \%$ dengan rincian ketersediaan sarana pembelajaran $66,7 \%$, penempatan sarana pembelajaran $75 \%$, kebermaknaan sarana pembelajaran $75 \%$, dan kelayakan sarana pembelajaran $75 \%$. Hasil ratarata observasi yang diperoleh pada siklus III adalah $70,8 \%$ dengan rincian ketersediaan sarana pembelajaran $58,3 \%$, penempatan sarana pembelajaran $75 \%$, kebermaknaan sarana pembelajaran $75 \%$, dan kelayakan sarana pembelajaran $75 \%$.

Berdasarkan analisis hasil tersebut sarana merupakan salah satu faktor yang mempengaruhi motivasi siswa untuk mengikuti pembelajaran, sarana berupa media pembelajaran dapat dimanfaatkan dengan baik oleh guru, namun karena ruangannya yang panas dan tempat duduk kurang nyaman membuat siswa seringkali tidak fokus dengan pembelajaran yang diberikan. Salah satu cara yang dapat diterapkan penggunaan kipas angin agar ruangan tersebut tidak terlalu panas dan siswa dapat lebih fokus dengan pembelajaran.

Komponen linkungan dalam pengamatan observasi hal yang diperhatikan yaitu: kenyamanan, ketenangan, kebersihan, dan keindahan. Hasil observasi rata-rata yang diperoleh pada siklus I adalah 58,3\% dengan rincian kenyamanan $41,7 \%$, ketenangan $50 \%$, kebersihan $75 \%$, dan keindahan $66,7 \%$, dengan kata lain bahwa kenyamanan dan ketenangan masih harus ditingkatkan untuk siklus II.

Hasil observasi rata-rata yang diperoleh pada siklus II adalah $66,7 \%$ dengan rincian kenyamanan 58,3\%, ketenangan $58,3 \%$, kebersihan $75 \%$, dan keindahan $75 \%$, dimana terlihat bahwa kenyamanan dan ketenangan belum ada peningkatan. Hasil observasi ratarata yang diperoleh pada siklus III adalah $64,6 \%$ dengan rincian kenyamanan $58,3 \%$, ketenangan $58,3 \%$, kebersihan $66,7 \%$, dan keindahan $75 \%$, dan kenyamanan serta ketenangan masih tetap belum ada peningkatan.

Berdasarkan analisis hasil tersebut secara keseluruhan ruang yang digunakan sudah cukup bersih. Namun, karena ruangan tesebut luas dan juga digunakan oleh kelas lain terkadang membuat konsetrasi siswa menjadi terpecah, selain itu suasana ruang yang panas membuat siswa ataupun guru merasa tidak nyaman.

\section{SIMPULAN}

Berdasarkan penelitian yang telah dilaksanakan pada siklus I, II, dan III maka dapat disimpulkan bahwa Penerapan model pembelajaran Problem Posing dapat meningkatkan hasil belajar kompetensi Mengaplikasikan Rangkaian Listrik siswa klas X TOI SMK N 2 Depok Sleman tahun ajaran 2018/2019. Hasil belajar siswa tahun ajaran 2017/2018 yang tanpa penerapan model pembelajaran Problem Posing pada materi I dari 32 siswa tuntas 11 siswa atu $34,38 \%$, pada materi II tuntas 8 siswa atau $25 \%$, pada materi III tuntas 13 siswa atau 40,63\%. Hasil belajar siswa tahun ajaran 2018/2019 yang menerapkan model pembelajaran Problem Posing, pada materi I/siklus I dari 32 siswa tuntas 9 siswa atau $28,1 \%$, pada materi II/siklus II tuntas 22 siswa atau $68,75 \%$, pada materi III/siklus III tuntas 24 siswa atau $75 \%$. Berdasar kriteria keberhasilan tindakan yang diajukan yaitu, jika persentase ketuntasan siswa yang memenuhi KKM 78 lebih dari $70 \%$ dari keseluruhan siswa kelas X TOI maka telah terjadi peningkatan kompetensi mengaplikasikan rangkaian listrik melalui penerapan metode pembelajaran Problem Posing pada siklus/materi III. Model Pembelajaran Problem Posing yang cocok diterapkan adalah tipe Post Solution Posing dengan tiap-tiap siklus meliputi: perencanaan, tindakan dan observasi, refleksi.

\section{DAFTAR RUJUKAN}

Danish Ministry of Education. 2014. Improving Vocational Education and Training- 
overview of reform of the Danish vocational education system. Denmark: Author.

Coe R., Aloisi C., Higgins S., \& Major L. E. 2014. What makes great teaching? Review of the underpinning research. Durham

Blazar, David. 2016. Teacher and Teaching Effects on Students' Academic Performance, Attitudes, and Behaviors. Doctoral dissertation, Harvard Graduate School of Education. Accessed January 4, $2018 \quad 2: 42: 39 \quad$ AM $\quad$ EST http://nrs.harvard.edu/urn3:HUL.InstRepos:27112692

Shoimin, A. 2014. Model Pembelajaran Inovatif dalam Kurikulum 2013. Yogyakarta: Ar-Ruzz Media

Rahman, A., \& Ahmar, A. S. 2017. Problem Posing of High School Mathematics Student's Based on Their Cognitive Style. Educational Process: International Journal, 6(1), 7-22.

Habila Elisha Zuya. 2017. The Benefits Of Problem Posing In The Learning Of
Mathematics: A Systematic Review. Int. J. Adv. Res. 5(3), 853-860 853 ISSN: 2220-5407 DOI: 10.21474/IJAR01/3581. DOI

URL: http://dx.doi.org/10.21474/IJAR01/3581

Mahmudi, A. 2008. Pembelajaran Problem Posing untuk Meningkatkan Kemampuan Pemecahan Masalah Matematika. Makalah disampaikan pada Seminar Nasional Matematika diselenggarakan oleh Jurusan Matematika FMIPA UNPAD bekerjasama dengan Departemen Matematika UI, di Universitas Padjajaran

Nurkancana, W. \& Sumartana, P.P.N. 1986. Evaluasi pendidikan. Surabaya:Usaha Nasional

Ngalimun. 2014. Strategi dan Model Pembelajaran. Yogyakarta: Aswaja Pressindo

Zahra G., Bakar M.N, Golam R. J. 2013. Innovation in Teaching and Learning through Problem Posing Tasks and Metacognitive Strategies. International Journal of Pedagogical Innovations. Int. J. Ped. Inn. 1, No. 1, 53-62 